\title{
PENGENALAN TEKNIS PENULISAN KARYA TULIS ILMIAH DAN BIMBINGAN TEKNIS PENERBITAN ARTIKEL PADA JURNAL ILMIAH BAGI GURU-GURU SD,SMPN 6 SATAP DI KECAMATAN SEPAUK
}

\author{
Dwi Cahyadi Wibowo', Sijono $^{2}$, \& Thomas Joni Verawanto Aristo ${ }^{3}$ \\ ${ }^{1}$ Program Studi PGSD, STKIP Persada Khatulistiwa \\ ${ }^{2,3}$ Program Studi Pendidikan Bahasa Inggris, STKIP Persada Khatulistiwa \\ Email:dwicahyadiwibowo@gmail.com,sijonostg4@gmail.com,thomaspaoh@gmail.com
}

\begin{abstract}
A lack of understanding of how to conduct classroom action research triggers the reality that teachers are still reluctant to carry out research. PKM team of STKIP STKIP Persada Khatulistiwa Sintang provides assistance and guidance in carrying out classroom action research and provides technical assistance for teachers to be able to publish their research results. In general, this PKM was conducted with training methods in the form of presentations and explanations of the CAR methodology as well as technical guidance for scientific journal publications with methods of implementing activities online. This activity was attended by 20 teachers from SD-SMPN 6, Sepauk District, Sintang District. The output of the service activities carried out at SD-SMPN 6 SATAP Sepauk achieved the planned target. This PKM activity was attended by more than $80 \%$ of teachers from SD-SMPN 6 SATAP Sepauk, although not $100 \%$ of this number were able to participate from the beginning of the activity due to internet network problems. During the activity, the teachers responded very well to this PKM activity. The teachers are excited to do research and some of them try to do research for promotion and at least $30 \%$ of the teachers intend to conduct research collaborations with PKM members.
\end{abstract}

Keywords: Technical Introduction; Technical guidance; Scientific papers

ABSTRAK: Kurangnya pemahaman bagaimana melakukan penelitian tindakan kelas memicu realita bahwa guru masih enggan melaksanakan penelitian. Guna membantu guru dalam meningkatkan kompetensi dalam melaksanakan penelitian tindakan kelas, maka tim PKM STKIP Persada Khatulistiwa Sintang melakukan pendampingan dan bimbingan dalam melaksanakan penelitian tindakan kelas serta melakukan pendampingan teknis bagi para guru untuk dapat mempublikasi hasil penelitiannya. Secara umum kegiatan PKM ini dilaksanakan dengan metode pelatihan berupa presentasi dan penjelasan tentang metodologi PTK serta bimbingan teknis publikasi jurnal ilmiah dengan metode pelaksanaan kegiatan secara daring. Kegiatan ini diikuti oleh 20 guru SD-SMPN 6 Kecamatan Sepauk Kabupaten Sintang. Luaran kegiatan pengabdian yang dilakukan di SD-SMPN 6 SATAP Sepauk mencapai target yang direncanakan. Kegiatan PKM ini diikuti oleh lebih dari 80\% guru dari SD-SMPN 6 SATAP Sepauk, walaupun tidak $100 \%$ dari jumlah tersebut dapat mengikuti dari awal kegiatan karena kendala jaringan internet. Selama kegiatan berlangsung respon para guru sangat baik terhadap kegiatan PKM ini. Para guru menjadi bersemangat untuk melakukan penelitian dan beberapa diantaranya berupaya melakukan penelitian untuk kenaikan pangkatnya serta setidaknya ada kurang lebih $30 \%$ guru berniat mengadakan kolaborasi penelitian dengan para anggota PKM.

Kata Kunci:Pengenalan Teknis; Bimbingan Teknis; Karya Tulis Ilmiah 


\section{PENDAHULUAN}

Peraturan pemerintah melalui Undang-undang No. 14 tahun 2005 tentang Guru dan Dosen, dimana peraturan tersebut menegaskan bahwa seorang guru harus mempunyai empat kompetensi yaitu kompetensi pedagogik, kepribadian, sosial dan professional. Dari keempat kompetensi tersebut, yang paling ditekankan dan dituntut untuk terus dikembangkan adalah kompetensi profesional. Menurut Undangundang No. 14 tahun 2005 tentang Guru dan Dosen kompetensi profesional adalah kemampuan seorang guru dalam penguasaan materi pelajaran secara luas dan mendalam serta dapat mengaplikasikannya ddengan baik dalam tugasnya sebagai pengajar atau pendidik. Kompetensi profesional menuntut seorang guru agar menjadi mahir yang meliputi meliputi kepakaran atau keahlian dalam bidangnya dimana guru tersebut mampu menguasi materi pembelajaran yang harus diajarkannya beserta mampu merancang bahkan mengembangkan metode pembelajarannya, selain itu guru yang profesional adalah guru yang memiliki rasa tanggung jawab yang besar akan tugasnya dan rasa kebersamaan dengan sejawat guru lainnya. Perkembangan kebijakan pendidikan di Indonesia melalui Kementrian Pendidikan Nasional menuntut bahwa seorang guru harus mempunyai sejumlah kompetensi untuk selalu meningkatkan kualitas pembelajaran di dalam kelas. Reward dari upaya guru dalam meningkatkan kompetensi ini salah satunya diwujudkan pemerintah melalui Direktorat Jenderal Pendidikan Tinggi, Kementrian Pendidikan Nasional dengan memberikan tunjangan profesi bagi guru yang lolos program sertifikasi guru. Upaya tersebut dilakukan semata-mata untuk meningkatkan kemampuan kompetensi guru dan untuk memotivasi para guru yang belum dapat mengembangkan kompetesinya dengan baik dalam meningkatkan kualitas manajemen dan pengelolaan pembejaran di sekolah. Salah satu kompetensi guru yang diharapkan dikembangkan adalah kemampuan guru melihat sebuah kelas sebagai suatu laboratorium untuk menemukan dan menyelesaikan masalah-masalah yang yang sering dihadapi baik oleh siswa maupun guru dalam proses pembelajaran secara keseluruhan. Permasalahan tersebut selanjutnya perlu ditindaklanjuti dengan mengadakan penelitian tindakan kelas yang hasil akhirnya tidak hanya meningkatkan kualitas proses pembelajaran secara keseluruhan, namun aktivitas penelitian juga dapat meningkatkan kemampuan dan ketrampilan serta profesionalisme guru. Dalam UU No. 20 tahun 2003 guru disebut sebagai pendidik, dalam hal ini pendidik 
adalah tenaga kependidikan yang berkualifikasi sebagai guru, dosen, konselor, pamong belajar, widyaiswara, tutor, instruktur, fasilitator dan sebutan lainnya yang sesuai dengan kekhususannya, serta berpartisipasi dalam penyelenggaraan pendidikan.

Sisdiknas no 20 tahun 2003; 5). Selanjutnya dalam BAB XI, pasal 39 disebutkan bahwa Pendidik merupakan tenaga professional yang bertugas merencanakan dan melaksanakan pembimbingan dan pelatihan, serta melakukan penelitian dan pengabdian masyarakat. Dalam UU tersebut ditekankan bahwa seorang guru juga harus melaksanakan penelitian untuk mengembangkan

kompetensinya.

Dikatakan disana guru harus melakukan tugasnya dengan baik salah satunya wajib melakukan penelitian, dalam hal ini guru dituntut untuk melakukan penelitian tidak hanya untuk syarat sertifikasi atau untuk keperluan jabatan fungsional semata. Melihat tugas dan kewajiban seorang guru yang tertuang dalam UU tersebut maka dapat dikatakan Guru merupakan profesi atau pekerjaan yang memerlukan keahlian khusus atau profesioanalisme guru. Artinya pekerjaan guru dan profesionalismenya adalah sebuah profesi yang tidak dapat dilakukan oleh sembarangan orang Usman (2006: 6). Namun kenyataan di lapangan menunjukkan bahwa banyak guru yang tidak melakukan tugas penelitiannya. Salah satu alasan guru tidak melakukan penelitan khususnya penelitian tindakan kelas adalah kurangannya pemahaman guru tentang metode penelitian tersebut, selain itu banyak guru yang berpikir melakukan penelitian hanya untuk keperluan sertifikasi saja. Sehingga banyak guru yang melakukan penelitian karena tuntutan sertifikasi semata. Hal ini dapat menyebabkan guru lupa dengan metode penelitain tindakan kelas. Kurangnya pemahaman bagaimana melakukan penelitian tindakan kelas memicu realita bahwa guru masih enggan melaksanakan penelitian. Selain itu mereka juga berpikir, melaukan penelitian adalah suatu kegiatan yang sangat berat yang hanya akan menambah beban tugas mengajar mereka.

Untuk mengatasi permasalahan tersebut diatas dalam rangka membantu guru dalam meningkatkan kompetensi mereka, terutama kompetensi dalam melaksanakan penelitian tindakan kelas, maka STKIP Persada Khatulistiwa Sintang sebagai salah satu mitra masyarakat dalam dunia pendidikan melalui program pengabdian kepada masyaratkat (PKM), perlu melakukan pendampingan dan bimbingan teknis dalam melaksanakan penelitian tindakan kelas, tidak hanya itu tim PKM jug akan melakukan pendampingan bagi para guru untuk dapat 
mempublikasi hasil penelitian mereka. Hal ini perlu dilakukan karena semua penelitian yang dilakukan oleh guru harus dipublikasikan dalam jurnal ilmiah. Dalam hal ini tim PKM yang terdiri dari tiga orang dosen tetap STKIP Persada Khatulistiwa Sintang juga melakukan pendampingan atau bimbingan teknis publikasi jurnal ilmiah serta memfasilitasi para guru dengan jurnal-jurnal yang ada di STKIP Persada Khtulistiwa Sintang diantaranya Juranl JEES dan VOX Edukasi yang sudah terakreditasi Nasional. Materi utama yang disampiakan dalam PKM tersebut adalah pemahaman dan prosedur penelitian tindakan kelas(PTK). Penelitian tindakan kelas atau disebut PTK adalah penelitian yang mengangkat masalah masalah yang aktual yang dilakukan oleh guru yang merupakan pencermatan kegiatan belajar yang berupa tindakan untuk memperbaiki dan meningkatkan praktik pembelajaran di kelas secara lebih profesional (Taniredja, Pujiati dan Nyata, 2010:16-17). Menurut Wahidmurni \& Ali (2008:14) "Penelitian Tindakan Kelas diartikan sebagai upaya atau tindakan yang dilakukan oleh guru atau peneliti untuk memecahkan masalah pembelajaran melalui penelitian (Sanjaya. W. 2009:26). Aqib Z (2009:13) menyatakan bahwa penelitian tindakan kelas merupakan suatu pencermatan terhadap kegiatan yang sengaja dimunculkan dan terjadi dalam kelas. Dengan demikian PTK dapat diartikan sebagai suatu pencermatan terhadap kegiatan belajar melalui sebuah tindakan yang sengaja dimunculkan dan terjadi dalam kelas secara bersamaan (Suwandi.2010:10). Berdasarkan pendapat para ahli, dapat disimpulkan bahwa penelitian tindakan kelas merupakan bagian dari proses pembelajaran yang tidak dapat dipisahkan dari peran seorang guru yang tugasnya tidak hanya mengajar namun juga melakukan refeksi yang dapat dituangkan dalam suatu penelitian. Oleh karenanya seorang guru harus memahami dengan baik metode penelitian tindakan kelas dan perlu mendapatkan pendampingan serta pelatihan dari perguruan tinggi. Dengan demikian, pendampingan tersebut nantinya diharapkan dapat memicu minat guru untuk selalu meningkatkan kualitas pembelajaran di kelas dengan merefleksikannya dalam bentuk penelitian tindakan kelas. Untuk mewujudkan harapan tersebut tim PKM melaksanakan suatu pelatihan dengan judul "Pengenalan teknis penulisan karya tulis ilmiah dan bimbingan teknis penerbitan artikel pada jurnal ilmiah bagi guru-guru SD,SMPN 6 SATAP di Kecamatan Sepauk". Tim PKM melakukan pelatihan di SD dan SMPN 6 Satu Atap Sepauk, karena sekolah tersebut merupakan sekolah mitra STKIP Persada Khatulistiwa Sintang dalam 
program PPL-PKM. Selain itu, kegiatan PKM tersebut terlaksana juga atas permintaan pribadi dari kepala sekolah yang menginginkan agar guru-guru di sekolah tersebut mendapatkan pendampingan dan pelatihan dalam melaksanakan penelitian tindakan kelas. Sasaran kegiatan ini adalah para guru-guru di SD dan SMPN 6 SATAP kecamatan Sepauk dengan jumlah peserta kurang lebih 20 orang. Kegiatan ini dilaksanakan pada bulan November-Desember 2020. Inti dari kegiatan ini adalah agar dapat memotivasi para guru untuk selalu meningkatkan kualitas pembelajaran di kelas dengan merefleksikannya dalam bentuk penelitian tindakan kelas. Dengan demikian penelitian tindakan kelas sebagai hasil refleksi guru pada akhirnya dapat meningkatkan meningkatkan kompetensi guru sekaligus menempatkan guru sebagai problem solver terhadap permasalahan-permasalahan yang ditemukan dalam proses belajar-mengajar di dalam maupun di luar kelas. Tujuan Kegiatan PKM ini adalah untuk memberikan penjelasan dan pelatihan tentang metode penelitian tindakan kelas(PTK) bagi para guru dan memberikan pelatihan teknis dan memfasilitasi para guru tentang tata cara penerbitan hasil penelitiannya pada jurnal ilmiah. Sasaran program PKM dengan judul 'Pengenalan teknis penulisan karya tulis ilmiah dan bimbingan teknis penerbitan artikel pada jurnal ilmiah bagi guru-guru SD,SMPN 6 SATAP di Kecamatan Sepauk' yang dilakukan dalam bentuk ini yaitu para dewan guru SD dan SMPN 6 SATAP Kecamatan Sepauk, Kabupaten Sintang Kalimantan Barat. Dalam pelaksanaan kegiatan PKM ini diharapkan dapat memberikan kontribusi terhadap kompetensi guru berupa pemahan dan penyegaran dalam bidang penelitian, khususnya penelitian tindakan kelas (PTK). Hasil laporan kegiatan ini diharapkan dapat diterbitkan pada di jurnal pengandian kepada masyarakat ber-ISSN.

\section{METODE PELAKSANAAN}

Secara umum kegiatan PKM dengan judul "Pengenalan teknis penulisan karya tulis ilmiah dan bimbingan teknis penerbitan artikel pada jurnal ilmiah bagi guru-guru SD,SMPN 6 SATAP di Kecamatan Sepauk" ini dilaksanakn dengan metode pelatihan berupa presentasi dan penjelasan tentang metodologi PTK. Mengingat masa pandemi, maka kegiatan tersebut dilaksanakan secara daring melalui aplikasi ZOOM. Hal ini dapat terlaksana mengingat sekolah mitra telah memiliki fasilitas yang dapat mendukung kegiatan ini dilaksanakan secara daring atau melalui aplikasi Zoom. Setelah mengikuti kegiatan ini, setiap peserta dan anggota tim 
pelaksana akan memperoleh sertifikat.

Secara umum metode pelaksanaan dalam kegiatan PKM ini adalah dengan melakukan beberapa langkah berikut ini:

1. Memberikan pemahaman kepada para guru tentang konsep dasar PTK.

2. Menjadikan guru terampil dalam menulis artikle.

3. Meningkatkan motivasi para guru untuk melakukan PTK.

4. Mendorong para guru untuk melakukan publikasi ilmiah.

Sedangkan materi yang disampaikan dalam penelitian ini adalah sebagi berikut:

1. Prinsip-prinsip dasar/paradikma mengenai penelitian tindakan kelas.

2. Tujuan penelitian tindakan kelas dan arti penting penelitian tindakan kelas.

3. Proses-proses dalam penelitian tindakan kelas.

4. Langkah-langkah persiapan penelitian tindakan kelas (Menyeleksi dan menetapkan topic).

5. Teknik pengumpulan data dalam PTK.

6. Teknik analisis data penelitian tindakan kelas.

7. Teknis publikasi artikel pada jurnal ilmiah.

8.

\section{HASIL DAN PEMBAHASAN}

Kegiatan pelatihan pengabdian dengan judul "Pengenalan teknis penulisan karya tulis ilmiah dan bimbingan teknis penerbitan artikel pada jurnal ilmiah bagi guru-guru SD,SMPN 6 SATAP di Kecamatan Sepauk ini dilaksanakan di SD-SMPN 6 Satap Kecamatan Sepauk, Kabupaten Sintang Kalimantan Barat pada tanggal 26 Oktober 2020 dengan metode daring. Kegiatan ini dilaksanakan dengan menggunakan aplikasi Zoom, metode pelaksanaan ini dipilih untuk menghindari kerumunan dan juga merupakan permintaan dari para kepala sekolah agar kegiatan tersebut dapat dilaksanakan secara daring. Selain itu kedua sekolah telah memiliki fasilitas yang cukup memadai untuk melaksanakan kegiatan ini secara daring.

Kegiatan ini diikuti oleh 20 peserta guru SD-SMPN 6 Kecamatan Sepauk Kabupaten Sintang. Luaran kegiatan pengabdian yang dilakukan di SD-SMPN 6 SATAP Sepauk mencapai target yang direncanakan. Meskipun dilaksanakan secara daring dan sempat mengalami sedikit kendala sinyal yang kurang baik diawal kegiatan, kegiatan PKM ini diikuti oleh lebih dari 80\% guru dari SD-SMPN 6 SATAP Sepauk walaupun tidak $100 \%$ dari jumlah tersebut dapat mengikuti dari awal kegiatan. Selama kegiatan berlangsung respon para guru sangat baik terhadap kegiatan PKM ini. Para guru menjadi bersemangat untuk mengupayakan 
kenaikan pangkatnya serta setidaknya ada kurang lebih 30\% guru berniat mengadakan kolaborasi penelitian dengan para anggota PKM. Hasil Kegiatan PKM ini berupa pelatihan dan pendampingan dalam penulisan karya ilmiah penelitian tindakan kelas bagi para guru di SD-SMPN 6 Satap Kecamatan Sepauk. Kegiatan ini terlaksana melalui beberapa tahapan kegiatan.

\section{Tahap Persiapan}

Dalam tahap ini tim pelaksana kegiatan PKM melakukan koordinasi dengan pihak sekolah. Tujuan dari kegiatan ini untuk memperoleh ijin pelaksanan kegiatan dari kepala sekolah dan untuk mengetahui jumlah guru yang dapat mengikuti kegiatan tersebut serta untuk memperlancar pelaksanaan PKM. Hasil dari koordinasi ini adalah jadwal pelaksanaan PKM, pembagian tugas masing-masing anggota tim PKM dan pihak sekolah, serta guru yang berkomitmen mengikuti kegiatan ini. Dalam tahapan persiapan ini tim pelaksana PKM juga melakukan persiapan lainnya berupa penyusunan Bahan Pelatihan. Penyusunan bahan pelatihan dilakukan oleh tim PKM bertujuan memudahkan peserta dalam mengikuti kegiatan ini. bahan pelatihan berupa materi tentang metodologi penelitian tindakan kelas dengan contoh. Bahan pelatihan meliputi: konsep dasar PTK, prosedur PTK, teknik penyusunan proposal PTK, teknik pembuatan instrumen pengumpulan data PTK, teknik penyusunan laporan PTK, teknik penyusunan artikel hasil PTK dan teknis publikasi artikel pada jurnal ilmiah.

\section{Tahap Pelaksaan kegiatan}

Sasaran kegiatan PKM ini adalah para guru di SD-SMPN 6 Kecamatan Sepauk. Kegiatan ini berupa pelatihan dan penyuluhan yang diikuti lebih dari $80 \%$ guru yang ada di lingkungan SDSMPN 6 Satap Kecamatan Sepauk. Kegiatan ini dilaksanakan secara daring melalui aplikasi Zoom. Pelaksanaan kegiatan dimulai dengan sambutan dari Ketua Tim pelaksana kegiatan dan dilanjutkan dengan sambutan kepala SDN 16 Sepauk, dilanjutkan dengan pengenalan panitia kegiatan serta instruktur atau pemateri yang akan memberikan pengarahan selama kegiatan berlangsung. Sebelum kegiatan dimulai, kegiatan dibuka dahulu oleh moderator, sekaligus menyampaikan sekilas tentang tujuan kegiatan tersebut. Kegiatan awal dilakukan dengan melakukan positioning. Positioning dilakukan dengan melakukan tanya jawab tentang 
materi pelatihan. Hal ini dilakukan untuk memetakan kecenderungan cara berpikir guru sehingga memudahkan Tim PKM untuk melakukan pelatihan dan pendampingan. Hal ini juga dimaksudkan untuk memecahkan hambatan secara psikis antara Tim PKM dan guru-guru, serta hambatan secara psikis diantara para peserta pelatihan, sehingga melahirkan motivasi dan antusiasme mereka. Motivasi dan antusiasme para guru nampak pada keceriaan mereka dalam mengikuti kegiatan ini, mereka berani untuk berpartisipasi, mengungkapkan gagasan serta berkontribusi secara positif dalam kegiatan. Hampir 100\% peserta mengikuti kegiatan tersebut dengan penuh semangat, selama kegiatan berlangsung tidak seorang guru atau peserta yang meninggalkan tempat duduknya. Kegiatan inti adalah penyampai metri oleh tim pelaksana PKM, materi pelatihan meliputi: (1) Konsep Dasar PTK; (2) Prosedur PTK; (3) Teknik Penyusunan Proposal PTK; (4) Teknik Pembuatan Instrumen Pengumpulan Data PTK; (5) Teknik Penyusunan Laporan PTK; dan (6) Teknik Penyusunan Artikel Hasil PTK serta (7) teknis publikasi artikel pada jurnal ilmih. Kegiatan untuk membangun pemahaman terhadap konsep penelitian tindakan kelas dilakukan melalui ceramah dan diskusi yang diikuti dengan kegiatan umpan balik antara penyaji dan guru-guru. Berdasarkan hasil jawaban umpan balik yang disampaikan oleh para guru, menunjukkan bahwa guru-guru di SDSMPN 6 Satap Kecamatan Sepauk memahami konsep subtansial dari PTK dan prosedur yang harus dilakukan untuk melaksanakan PTK. Selain itu lebih dari $70 \%$ perserta tahu cara mempublikasi artikel pada jurnal ilmiah yang di rujuk oleh para pemateri (Jurnal JEES).

Setelah pemateri meyampaikan materi dan langkah-langkah proses penelitian dengan, dilanjutkan dengan tahapan tanya jawab tentang keseluruhan proses kegaitan PKM ini. Pada tahap tanya jawab, para guru terlihat antusias karena kegiatan ini belum pernah mereka dapatkan sebelumnya. Kegiatan pelatihan ini juga baru pertama kali diadakan di sekolah mereka. Dari hasil diskusi terlihat bahwa para guru sangat antusias dalam kegiatan pelatihan ini.

Adapaun beberapa guru memperlihatkan ketertarikan dan antusias yang sangat tinggi dalam mengikuti kegiatan ini. Dengan diadakannya kegiatan pelatihan dengan judul "Pengenalan teknis penulisan karya tulis ilmiah dan bimbingan 
teknis penerbitan artikel pada jurnal ilmiah bagi guru-guru SD,SMPN 6 SATAP di Kecamatan Sepauk” ini para guru menjadi termotivasi dalam belajar dan melakukan penelitian sehingga dapat meningkatkan kualitas pengajaran mereka. Penyampaian materi oleh pemateri tim juga dinilai sangat bagus, komunikatif, interaktif, menarik, dan sangat jelas. Dari segi pelaksanaan kegiatan, peserta menilai bahwa dalam hal waktu, tempat dan fasilitas kegiatan sudah baik. Berikut adalah saran-saran yang disampaikan oleh para peserta pelatihan untuk penyelenggaraan kegiatan yang sama pada masa yang akan datang. Sebagian besar menyarankan adanya tindak lanjut dari kegiatan ini yang berupa pendampingan atau bimbingan kepada guru-guru dalam melaksanakan PTK di sekolah masing-masing. Peserta juga menyarankan agar kegiatan semacam ini diadakan lagi secara rutin dengan penekanan pada aspek PTK yang berbedabeda dengan waktu penyelenggaraan yang lebih panjang sehingga guru dapat benarbenar berlatih. Dalam kegiatan PkM tersebut luaran yang diperoleh adalah pengetahuan dan teknik dalam meneliti terutama kemampuan meneliti dengan menggunakan PTK. Luaran lainnya adalah hasil laporan PkM tersebut diterbitkan pada jurnal lokal tentang pengabdian masyarakat.

\section{SIMPULAN}

Mitra pengabdian sangat puas dan menganggap kegiatan ini penting untuk dilakukan. Partisipasi aktif peserta serta hasil yang dicapai selama kegiatan ini menunjukkan kebermanfaatan pengabdian yang dilakukan oleh tim pengabdi. Kegiatan PKM ini diikuti oleh lebih dari $80 \%$ guru dari SD-SMPN 6 SATAp Seapuk. Selama kegaitan berlangsung respon para guru sangat baik terhadap kegiatan PKM ini. Para guru menjadi bersemangat untuk mengupayakan kenaikan pangkatnya serta kurang lebih $30 \%$ para guru berniat mengadakan kolaborasi penelitian dengan para anggota PKM. Hal ini menunjukan bahwa hasil yang diharapkan dari kegiatan PKM ini sudah sesuai dengan target sehingga efektivitas pengabdian dapat dipertanggungjawabkan. Penyampaian materi mengenai konsep dasar PTK sudah tepat sasaran diberikan kepada guru-guru di lingkungan SD-SMPN 6 Satap Kecamatan Sepauk sesuai dengan latar belakang dilaksanakannya PKM ini. Seperti yang dijelaskan di dalam Bab 1, kegiatan PKM ini merupakan upaya membantu meningkatkan profesionalisme guru sekaligus juga melaksanakan aspek PKM sebagai bagian dari Tri Darma Perguruan Tinggi. Kegiatan ini juga telah memberikan kesempatan pada guru-guru untuk dapat 
berkolaborasi dengan para pemateri untuk melakukan penelitian bersama serta memperbaiki kualitas penelitian PTK yang sedang mereka buat. Hasil observasi dan analisis dari seluruh rangkaian kegiatan juga menunjukkan hal yang positif, yaitu adanya antusiasme para guru dalam mengikuti kegiatan dan keinginan mereka untuk dapat melaksanakan atau mempraktikkan apa yang telah mereka peroleh melalui kegiatan PPM ini.

\section{SARAN}

Setelah melakukan kegiatan PkM dengan judul "Pengenalan teknis penulisan karya tulis ilmiah dan bimbingan teknis penerbitan artikel pada jurnal ilmiah bagi guru-guru SD,SMPN 6 SATAP di Kecamatan Sepauk" dapat disarankan bahwa:

1. Kegiatan PKM tersebut sebaiknya juga dapat dilaksanakan dibeberapa sekolah lainya ataupun dilakukan dengan cakupan yang lebih luas, karena mengingat manfaat dari kegiatan tersebut sangat baik terutama bagi tenaga pengajar di desa-desa yang memerlukan pelatihan secara khusus.

2. Dana kegiatan untuk kegiatan PKM sebaiknya juga ditingkatkan sehingga tim peneliti dapat menyediakan alat dan bahan yang memadai untuk kegiatan PKM serta dapat meningkatkan durasi pelasaksanaan kegiatan PKM.

\section{UCAPAN TERIMAKASIH}

Tim pelaksana pengabdian mengucapkan terima kasih kepada Kepala SD-SMPN 6 SATAP Sepauk dan para guru SD-SMPN 6 SATAP Sepauk yang telah menjadi mitra dalam pelaksanaan pengabdian ini, LPPM STKIP Persada Khatulistiwa Sintang, serta pihak terkait lain yang telah membantu selama kegiatan.

\section{DAFTAR RUJUKAN}

Hadis, Abdul. 2006. Psikologi dalam Pendidikan. Bandung: Alfabeta

Hafid, Anwar, dkk. 2013. Konsep Dasar Ilmu Pendidikan. Bandung : Alfabeta

Usman U, M. (2006). Menjadi Guru Profesional. Bandung: PT. Remaja Rodaskara.

Undang-undang Republik Indonesia No 14 Tahun (2005), Tetang Guru dan Dosen. Departemen Pendidikan Nasional. Jakarta.

Undang-Undang Nomor 20 Tahun (2003). tentang Sistem Pendidikan Nasional. Departemen Pendidikan Nasional. Jakarta.

Aqib, Z. (2008). Penelitian Tindakan Kelas. Bandung: Ypramawidya. 
Sanjaya, W. (2009). Penelitian Tindakan

Kelas. Jakarta: Kencana Prenada Media Group

Suwandi, S. (2009). Penelitian Tindakan Kelas (PTK) dan Penulisan Karya Ilmiah. Kadipiro Surakarta: Yuma Pustaka

Wahidmurni, Ali Nur. (2008). Penelitian Tindakan Kelas Pendidikan Agama Islam dan Umum Dari teori Menuju Praktik Disertai contoh Hasil Penelitian. Malang: UM Press

Taniredja, T., dkk. (2010). Pendidikan Kewarganegaraan di Perguruan Tinggi Muhammadiyah: Bandung: Alfabeta. 